\title{
The Effect of Social Support on Pregnancy-Related Anxiety in First Trimester Expecting Mothers
}

\author{
Caroline Zefanya ${ }^{1}$ Denrich Suryadi ${ }^{*}$ \\ ${ }^{1}$ Faculty of Psychology, Universitas Tarumanagara, West Jakarta, Indonesia \\ "Corresponding author. Email: denrichs@fpsi.untar.ac.id
}

\begin{abstract}
During pregnancy, a mother will experience physical, hormonal, and social changes that affect the mother's psychology and emotion. When the mother's psychological and emotional state changes, the baby's development will be affected. Expecting mothers in the first trimester are prone to anxiety, one of which is pregnancy-related anxiety which will be further discussed in this study. Anxiety in expecting mothers can be suppressed by providing social support to expecting mothers. In this study, the authors wanted to further investigate the effect of social support on pregnancy-related anxiety. This study aims to determine whether or not social support has an effect on pregnancy-related anxiety in first trimester expecting mothers. This study used non-experimental quantitative method with a snowball sampling technique to select participants. Total first trimester expecting mothers who filled out this questionnaire were 184 participants who lived in Jakarta and were 18-30 years old. The results of the linear regression test show a significance value of $0.034<0.05$. It can be concluded that there is a significant effect of social support on pregnancy-related anxiety. With the regression equation of $\mathrm{Y}=2.453-0.081 \mathrm{X}$ and the amount of influence as much as $2.5 \%$, the rest is influenced by other factors not examined in this study. The regression coefficient value in the regression equation is negative, indicating that social support has a negative effect on pregnancy-related anxiety.
\end{abstract}

\section{Keywords: Social support, pregnancy-related anxiety, expecting mothers, first trimester}

\section{INTRODUCTION}

During the social distancing period, there were a number of clinics that were closed or at risk of transmitting COVID-19, making it difficult for married couples to consult about reproductive health, regulating the number of births and using the right contraception. This led to increase in pregnancy rate in 2020 [25].

During pregnancy, the mother will experience a period in which her psychological, physical, hormonal, and social conditions change [9]. These changes will affect the psychological and emotional condition of the mother [9] which also affect infant development [11], premature birth and low birth weight [10], and reducing the quantity of breast milk [18], smoking and drug abusing behavior [13], and if coupled with low social support, can develop into prenatal depression $[14,17,30]$.

Psychological conditions that can be affected by changes in pregnancy include mood swings, fatigue [12], anxiety, and depression [3]. Anxiety is a behavioral disorder of fear and excessive anticipation of things that are considered threatening [1] and is one of the most common psychological disorders experienced by mothers during their pregnancy $[6,14,28]$.

There are several types of anxiety that a mother can experience during pregnancy, one of which is pregnancyrelated anxiety. Pregnancy-related anxiety $(\operatorname{PrA})$ is characterized by the appearance of feelings of fear and worry in expecting mothers. Mothers who experience PrA have a risk of preterm birth in infants [4]. PrA can also increase the risk of complications of pregnancy and childbirth. This is stated in the results of the research by Hoyer et al. who reported that there was a relevant association between $\operatorname{PrA}$ and complications during pregnancy and delivery [16]. Expecting mothers who lack social support are more prone to experiencing symptoms of anxiety than expecting mothers who receive enough social support [22,31].

Apart from symptoms of anxiety, social support can also reduce the risk of low birth weight in infants, the risk of early birth, and reduce pregnancy complications $[13,15]$. More specifically, it is explained in the results of other studies that support from husband and family [19] plays a role in the emergence of anxiety symptoms in expecting mothers $[21,23,30]$. Of the three trimester periods, the risk of anxiety disorders in expecting mothers is highest in the first trimester and decreases until the third trimester [11-12, 30, 32].

Some of the studies that have been mentioned only examined the relationship between variables; therefore, the authors seek to further investigate the effect of social support on pregnancy-related anxiety in expecting mothers. In this study, the authors wanted to review the research on the relationship between social support and 
anxiety in third trimester expecting mothers conducted by [19] with regression analysis techniques to test the effect between variables and instead uses first trimester expecting mothers.

\subsection{Research Question and Research Objectives}

The research question of study is whether social support affects pregnancy-related anxiety in first trimester expecting mothers, while the aim of the study is to determine whether or not social support has an effect on pregnancy-related anxiety in first trimester expecting mothers.

\subsection{Theoretical and Practical Benefit}

The theoretical benefit of this research is to broaden the readers' insight regarding the importance of social support and health for expecting mothers during their pregnancy. The practical benefit of this research is to raise awareness of the public about the importance of mental health for expecting mothers to encourage them to provide social support.

\subsection{Writing Systematics}

Furthermore, in chapter two we will discuss the definitions and dimensions of each variable, research hypotheses, and participant criteria. In chapter three, the sample, types of research, research settings, and processing and data analysis techniques will be discussed. Then in chapter four the results of assumption tests, hypothesis testing, and additional data will be discussed. Finally, chapter five will discuss research results, practical suggestions, and theoretical suggestions from the authors.

\section{LITERATURE REVIEW}

\subsection{Pregnancy-related Anxiety Definition}

Anxiety is a normal behavior that helps individuals to be alert in a threatening situation [38]. Anxiety is also defined as a form of emotion which is characterized by feelings of pressure, worry, and changes in body condition [37]. There are three types of anxiety in expecting mothers, general anxiety, anxiety disorders, and pregnancy-related anxiety. Pregnancy-related anxiety is a type of anxiety that includes fear and worry experienced by women during pregnancy, childbirth, the well-being of themselves and their babies, matters related to hospitals and nursing staff, physical changes, family life, and the role of a mother [5]. Bayrampour et al define PrA as a state of fear and anxiety about the health of the baby and mother, the health care system, social and financial problems related to the context of pregnancy, childbirth and care, accompanied by excessive worry and somatic symptoms [36]. Meanwhile,
Wall et al. argued that PrA is anxiety in expecting mothers characterized by anxiety during pregnancy or childbirth, maternal and infant health, quality and accessibility of health facilities, and the ability to care for the baby [39]. Based on the literature above, it can be concluded that pregnancy-related anxiety (PrA) is a feeling of fear or worry experienced by expecting mothers regarding the health of the baby, herself, and the mother's social environment.

\subsection{Pregnancy-related Anxiety Dimensions}

According to Brunton et al., Pregnancy-related anxiety (PrA) has eight dimensions, namely Childbirth Concerns, Body Image Concerns, Attitudes towards Childbirth, Worry about Self, Acceptance of Pregnancy, Attitudes towards Medical Staff, Avoidance, and Baby Concerns [5]. The dimension of childbirth concerns contains items related to maternal concerns and fears about childbirth The dimension of attitudes towards childbirth indicate that the mother is ready physically, mentally, and emotionally to face childbirth.

Furthermore, the dimension of worry about self is a combination of worry about motherhood with anxiety indicators. In the dimension of worry about motherhood, discusses the development of women to accept their new role as mothers and see themselves for the first time as mothers. The dimension of anxiety indicators contains items that indicate that anxiety appears in the form of thoughts such as worry and fear, and in the form of physical symptoms similar to symptoms of panic.

The acceptance of pregnancy dimension refers to the mother's adaptive response to pregnancy. The dimension of attitude towards medical staff contain items related to maternal trust in medical staff. The avoidance dimension has the potential for avoidance behavior to overcome anxiety and pregnancy stress. The last dimension, baby concerns, indicates a concern about the welfare of the baby in the womb [5].

\subsection{Social Support Definition}

Social support according to Zimet, which is taken from the notion put forward by Tardy (1985) is defined through five dimensions, including direction (whether support is provided or received), disposition (whether support is available and used), objectivity / subjectivity (description of supporting resources or evaluation of satisfaction with support), content (what form of support is received), and network (what is the structure of the social system that provides support) [34]. Social support is defined as assistance and protection in emotional, information, and tangible form provided by the environment to groups or individuals [29]. Another definition from Shumaker says that social support is the exchange of resources between two or more individuals who are considered by the individual to increase the welfare of the recipient [27].

Based on the definition above, it can be concluded that social support is an exchange of assistance in the form of 
emotional, informational, or tangible assistance between two or more individuals where each individual feels satisfaction with the fulfillment of their social needs.

\subsection{Social Support Dimensions}

According to Zimet et al, social support consists of three dimensions, namely social support from friends, family, and significant people. The family is considered a source of social support because in a family there is mutual trust in one another. Family can also be a place to tell stories when an individual wants to share their problems. Likewise with friends, in friendship one will find solidarity among friends. The nature of solidarity is shown by supporting, maintaining, and giving both material and nonmaterial things. Apart from family and friends, meaningful people are one of the important people for the mother in influencing the overall situation of the individual by being present when needed, being able to share complaints, provide comfort, and care about what the individual feels [35].

Support from partners makes expecting mothers calmer and less anxious [7]. This will minimize anxiety disorders caused by the pregnancy and childbirth process [26].

\subsection{First Trimester Expecting Mothers}

When a woman realizes that she has missed her menstrual schedule, that is the first possible sign of pregnancy appear. In addition, early signs of pregnancy that can occur are fatigue, pain in the breasts, sensitivity to certain smells or foods, or low body temperature [24]. The first trimester of pregnancy is considered the shortest trimester compared to other trimesters. During this time the mother will experience early pregnancy symptoms such as sore and enlarged breasts, flatulence caused by hormonal changes, nausea, and fatigue [24].

During the first days of pregnancy, it is very common for expecting mothers to feel anxiety [33]. The gestation period usually lasts about nine months or forty weeks. A healthy pregnancy mostly occurs in mothers under the age of thirty. Pregnancy in the 30-40s has a greater risk of miscarriage, infertility, and chromosomal abnormalities in babies [2]. The ideal age for women to experience pregnancy is 20-25 years. Women under 20 years of age are at risk of experiencing physical conditions or unexpected childbirth process, but those over 30 years old are also prone to experience anxiety due to physical conditions that are not as optimal as before which can affect the mother's psychological state. At the ideal age, mothers can also better cope with existing problems, so that feelings of worry or anxiety are still under control [26, 33].

\subsection{Research Hypothesis}

There is a significant effect of social support on pregnancy-related anxiety.

\section{METHODS}

This research is a non-experimental quantitative research with non-probability snowball sampling technique. The participant characteristics of this study are expecting mothers aged 18-30 years with a gestational age of less than 13 weeks (one to three months of pregnancy), and living in the Jakarta area. The number of participants were 184 expecting mothers, with 36 people $(19.6 \%)$ being 27 years of age, followed by participants who are 26 years old as many as 30 people $(16.3 \%)$, and at the third place are women aged 28 , as many as 28 people $(15.2 \%)$. The youngest participants were 18 years, as many as two people (1.1\%). More details are presented in Table 1.

Table 1 Participant Data Based on Age

\begin{tabular}{lll}
\hline Age & Frequency & Percentage \\
\hline 18 & 2 & 1.1 \\
26 & 30 & 16.3 \\
27 & 36 & 19.3 \\
28 & 28 & 15.2 \\
\hline
\end{tabular}

Then, there were 120 participants who were experiencing their first pregnancy and 64 participants who were not (see Table 2).

Table 2 Participant Data Based on Pregnancy Order

\begin{tabular}{lll}
\hline Pregnancy order & Frequency & Percentage \\
\hline First & 120 & 65.2 \\
Not First pregnancy & 64 & 34.8 \\
Total & 184 & 100.0 \\
\hline
\end{tabular}

In this study the majority of participants were living with their partners, with 172 participants living with their partners and the rest were not (see Table 3 ).

Table 3 Participant data based on family members who share the same residence

\begin{tabular}{lll}
\hline Living with partner & Frequency & Percentage \\
\hline Yes & 172 & 93.5 \\
No & 12 & 6.5 \\
Total & 184 & 100.0 \\
\hline
\end{tabular}

The author uses the Multidimensional Scale of Perceived Social Support (MSPSS) measurement tool developed by Zimet et al. as a measure of social support. Then to measure pregnancy-related anxiety the authors used a measuring instrument developed by Brunton et al. (2019), namely pregnancy-related anxiety scale (PrAS).

The author uses the google form to distribute questionnaires to participants during the pandemic. All questionnaire data were processed using the IBM Statistical Package for the Social Sciences Statistics (SPSS) software with linear regression analysis technique.

\section{FINDINGS AND DATA ANALYSIS}

Judging from the overall data, it can be concluded that participants received high level of social support and low 
pregnancy-related anxiety (see Table 4 ). In the normality assumption test, the Sig. (2-tailed) of 0.268>0.05 (see Table 5). It can be concluded that the data is normally distributed and the next stage can be tested for correlation and hypothesis testing with linear regression.

Table 4 Description of Research Variables

\begin{tabular}{lllll}
\hline & Minimum & Maximum & Mean & SD \\
\hline $\begin{array}{l}\text { Social } \\
\text { Support }\end{array}$ & 1.92 & 7.00 & 5.8501 & 0.86347 \\
$\begin{array}{l}\text { Pregnancy- } \\
\text { related } \\
\text { Anxiety }\end{array}$ & 1.09 & 3.41 & 1.9793 & 0.44635 \\
& & & & \\
\hline
\end{tabular}

The results of the correlation test obtained a significance value of 0.034 with a Pearson correlation value of -0.157 . It can be concluded that social support is negatively correlated with pregnancy-related anxiety (see Table 6). This finding supports the findings of Hopkins et al. and Hetherington et al. The study by Hopkins et al. found that high social support led to low anxiety and low maternalfetal attachment [15]. Then, Hetherington et al. concluded that low social support increases the risk of depression and anxiety symptoms at four months postpartum [14].

Table 5 Linear Regression Normality Test

\begin{tabular}{ll}
\hline & Unstandardized Residual \\
\cline { 2 - 2 } Kolmogorov-Smirnov Z & 1.011 \\
Asymp. Sig. (2-tailed) & 0.268 \\
\hline
\end{tabular}

Table 6 Pearson Correlation Test

\begin{tabular}{lll}
\hline & & $\begin{array}{l}\text { Pregnancy-related } \\
\text { Anxiety }\end{array}$ \\
\hline Social Support & Pearson & -0.157 \\
& Correlation & \\
& Sig. (2-tailed) & 0.034 \\
& $\mathrm{~N}$ & 184 \\
\hline
\end{tabular}

Hypothesis testing with linear regression resulted in a significance value of 0.034 . With the regression equation $\mathrm{Y}=2.453-0.081 \mathrm{X}$, it can be concluded that social support has a negative effect on pregnancy-related anxiety (see Table 7). Furthermore, the effect social support on pregnancy-related anxiety is $2.5 \%$ (see Table 8 ) and the rest is influenced by other variables which will be discussed later.

These results are similar to previous studies with a significance value of 0.01 and a regression coefficient of 0.311 [31]. Another study with similar results conducted on 40 expecting mothers showed that social support has an effect on anxiety in expecting mothers with a coefficient of -0.710 [21].

Physical and hormonal changes that occur during early pregnancy make women more susceptible to psychological changes [9]. So it is not uncommon during pregnancy that mothers often experience anxiety and require social support. There are three sources of social support which are family, friends, and significant others (partners).
Family and friends can provide support, be a place to tell stories, and share problems [35].

The role of a partner is not only to provide support, but also attitude, action, and acceptance of everything that happens to his wife. The support of a partner incites a feeling of calmness and comfort during the pregnancy process [8]. In addition, a partner is an important person for the mother in providing physical and emotional support, such as being present when needed, a place to share complaints, provide comfort, and give attention to what she is feeling [35].

The effect of social support on anxiety in this study is very weak, which is only $2.5 \%$. This can be caused by other factors or variables that were not involved in this research and difficult to control in this study, such as research being conducted online, fear of a pandemic, being unemployed, and also conflicts between family members [20].

Table 7 Linear Regression Hypothesis Test

\begin{tabular}{llll}
\hline \multirow{4}{*}{$\begin{array}{ll}\text { Unstandardized } \\
\text { Coefficients }\end{array}$} \\
\cline { 2 - 4 } Constant & $\mathrm{B}$ & $\mathrm{t}$ & Sig. \\
\cline { 2 - 4 } Social Support & 2.453 & 10.963 & 0.000 \\
\hline
\end{tabular}

Table $8 R$ Square Test

\begin{tabular}{lllll}
\multicolumn{2}{l}{ Table 8 $R$ Square Test } \\
\hline $\mathrm{R}$ & $R$ Square & $\begin{array}{l}\text { Adjusted } \\
\text { Square }\end{array}$ & $R$ & $\begin{array}{l}\text { Std. Error of } \\
\text { The Estimate }\end{array}$ \\
\hline 0.157 & 0.025 & 0.019 & 0.44204 \\
\hline
\end{tabular}

The results of the test for differences in pregnancy-related anxiety based on the mother's pregnancy count found $\mathrm{t}$ $(182)=0.482, p=0.630>0.05$ (see Table 9). Thus, it can be concluded that there is no significant difference in pregnancy-related anxiety between mothers who were experiencing their first pregnancy and mothers who were not in their first pregnancy.

This is in contrast to Rinata and Andayani's research which concluded that there were differences in mothers who experienced pregnancy for the first time and mothers who were in subsequent pregnancies [26].

According to Sondakh and Yuliani (2017), anxiety can be felt by both primigravida and multigravida mothers. Primigravida mothers can feel anxious due to inexperience and stories from friends or relatives about the process of pregnancy and childbirth or complications in pregnancy and childbirth [41]. Multigravida mothers can experience anxiety due to previous pregnancy experiences.

Table 9 Independent Sample T-Test

\begin{tabular}{|c|c|c|c|c|}
\hline \multirow[b]{3}{*}{$\begin{array}{l}\text { Pregnancy- } \\
\text { Related } \\
\text { Anxiety }\end{array}$} & \multirow[b]{3}{*}{$\begin{array}{l}\text { Equal } \\
\text { variances } \\
\text { assumed }\end{array}$} & \multicolumn{3}{|c|}{ t-test for Equality of Means } \\
\hline & & $\mathrm{t}$ & df & $\begin{array}{l}\text { Sig. (2- } \\
\text { tailed) }\end{array}$ \\
\hline & & 0.482 & 182 & 0.630 \\
\hline
\end{tabular}

The results of the test for differences in pregnancy-related anxiety based on family members living together obtained 
$\mathrm{t}$ value $(182)=-3.078, \mathrm{p}=0.002<0.05$ (see Table 10$)$. Thus, it can be concluded that there is a significant difference in pregnancy-related anxiety between expecting mothers who live with their partners and those who do not live with their partners.

In the dimension of social support in this study, it is stated that significant other (in this study referred to as a partner) is a person who can influence the mother's condition (psychologically and physically) by being present when needed by the mother, providing a sense of security and care for the mother's situation [35]. The results of this difference test are in accordance with the results of prior research conducted on 34 expecting mothers, which those who do not live with their partner lack support, resulting in high level of maternal anxiety [7]. Another similar study concluded that mothers who live with their partners show moderate to low anxiety [8]. Mothers who get support from their partners show reduced psychological disorders, especially anxiety caused by the pregnancy and childbirth process [26].

Table 10 Independent Sample T-Test

\begin{tabular}{|c|c|c|c|c|}
\hline \multirow[b]{3}{*}{$\begin{array}{l}\text { Pregnancy- } \\
\text { Related } \\
\text { Anxiety }\end{array}$} & \multirow[b]{3}{*}{$\begin{array}{l}\text { Equal } \\
\text { variances } \\
\text { assumed }\end{array}$} & \multicolumn{3}{|c|}{ t-test for Equality of Means } \\
\hline & & $\mathrm{t}$ & $\mathrm{df}$ & $\begin{array}{l}\text { Sig. (2- } \\
\text { tailed) }\end{array}$ \\
\hline & & -3.078 & 182 & 0.002 \\
\hline
\end{tabular}

Furthermore, the results of the difference test of pregnancy-related anxiety based on the mother's age reported that there was no significant difference in pregnancy-related anxiety between the older and younger mothers with $\mathrm{F}=1.354, \mathrm{p}=0.193<0.05$ using one way ANOVA test (see Table 11). This may be due to most of the participant being 26 to 28 years old, that this age range is within early adulthood [40]. In addition, 26 to 28 years of age is considered mature [26].

Table 11 One way ANOVA

\begin{tabular}{llllll}
\hline $\begin{array}{l}\text { Pregnancy- } \\
\text { Related } \\
\text { Anxiety }\end{array}$ & $\begin{array}{l}\text { Sum of } \\
\text { Squares }\end{array}$ & & $\begin{array}{l}\text { Mean } \\
\text { Square }\end{array}$ & F & Sig. \\
\hline $\begin{array}{l}\text { Between } \\
\text { Groups }\end{array}$ & 3.164 & 12 & 0.264 & 1.354 & 0.193 \\
$\begin{array}{l}\text { Within } \\
\text { Groups }\end{array}$ & 33.294 & 171 & 0.195 & & \\
Total & 36.458 & 183 & & & \\
\hline
\end{tabular}

The results of the social support difference test based on whether it is the mother's first pregnancy or not showed that there is a significant difference in social support between mothers experiencing their first pregnancy and mothers who were not in their first pregnancy with $\mathrm{t}$ (182) $=2.124, p=0.035<0.05$ (see Table 12). In line with the data in this study, in general, mothers who had their first pregnancy received slightly higher social support than mothers who had more than one pregnancy. This can be due to the social environment and the happy couple welcoming their first child. However, in reality, mothers who experience more than one pregnancy require higher social support because during the second pregnancy, the mother will be more physically and emotionally exhausted than when she was pregnant with her first child [25].

Table 12 Independent Sample T-Test

\begin{tabular}{lllll}
\hline & & \multicolumn{3}{c}{ t-test for Equality of Means } \\
\cline { 3 - 5 } Dukungan & $\mathrm{t}$ & $\mathrm{df}$ & $\begin{array}{l}\text { Sig. (2- } \\
\text { tailed) }\end{array}$ \\
\cline { 3 - 5 } $\begin{array}{l}\text { Sosial } \\
\text { variances } \\
\text { assumed }\end{array}$ & 2.124 & 182 & 0.035 \\
\hline
\end{tabular}

Contrary to the results of difference tests for social support based on the number of pregnancy, differences in social support based on family members who live together indicate that there is no significant difference with $\mathrm{t}(182)$ $=0.041, \mathrm{p}=0.968>0.05$ (see Table 13).

The results of prior research conducted by Diani and Susilawati (2013) showed that expecting mothers who live with their partners receive full informational, emotional, instrumental, and assessment support [8]. However, this research was conducted in 2013, when communication media was very different from the communication media available in 2020 .

Tabel 13 Independent Sample T-Test

\begin{tabular}{|c|c|c|c|c|}
\hline \multirow{3}{*}{$\begin{array}{l}\text { Social } \\
\text { Support }\end{array}$} & \multirow[b]{3}{*}{$\begin{array}{l}\text { Equal } \\
\text { variances } \\
\text { assumed }\end{array}$} & \multicolumn{3}{|c|}{ t-test for Equality of Means } \\
\hline & & $\mathrm{t}$ & df & $\begin{array}{l}\text { Sig. (2- } \\
\text { tailed) }\end{array}$ \\
\hline & & 0.041 & 182 & 0.968 \\
\hline
\end{tabular}

It was noted that during the COVID-19 pandemic, several pregnancy checks or consultations with obstetricians were conducted via telephone or messaging applications [42]. In a study, it was said that mothers who acquired information about pregnancy from social media have a lower risk of experiencing stress, anxiety, and depression than mothers who acquire information from family or friends [43].

Social support for expecting mothers can be obtained from three sources, namely family, friends and partners. The results of correlation test between the dimensions of social support and pregnancy-related anxiety showed that the dimension of family and friends were not significantly related to pregnancy-related anxiety. Meanwhile, the partner dimension has a significant relationship with pregnancy-related anxiety. This can be concluded from the results of the correlation test which shows a significance value of 0.003 and a pearson correlation value of -0.221 . In contrast to the partner dimension, the family dimension yields a significance value of 0.081 and a pearson correlation value of -0.129 . Likewise, with the friend dimension, the significance value was 0.514 and the Pearson correlation value was -0.048 (see Table 14). 
Table 14 Pearson Correlation Test of Dimensions of Social Support with Pregnancy-Related Anxiety

\begin{tabular}{lll}
\hline & & $\begin{array}{l}\text { Pregnancy- } \\
\text { Related Anxiety }\end{array}$ \\
\hline Partner & Pearson & -0.221 \\
& Correlation & \\
& Sig. $(2$-tailed) & 0.003 \\
& $\mathrm{~N}$ & 184 \\
Family & Pearson & -0.129 \\
& Correlation & \\
& Sig. (2-tailed) & 0.081 \\
& $\mathrm{~N}$ & 184 \\
Friends & Pearson & -0.048 \\
& Correlation & \\
& Sig. (2-tailed) & 0.514 \\
& $\mathrm{~N}$ & 184 \\
\hline
\end{tabular}

These results are supported by statements from Diani and Susilawati that the support provided by partners during pregnancy will strengthen the relationship between the couple so that the level of maternal anxiety can be suppressed [8]. The social support received by expecting mothers also makes them calm [7]. If expecting mothers receive support, especially from their partners, the tendency to experience psychological disorders, especially anxiety, will also decrease [26].

\section{CONCLUSION}

The results of the linear regression test produced the sig value equal to $0.001<0.05$, this means that there is a significant influence between variables. With a regression coefficient of -0.122 , this shows that social support has a negative effect on pregnancy-related anxiety. The author's suggestions for further research, if done online, can consider the level of education and socio-economic status of the participants in order for them to understand the questionnaire items properly. Then it can also be improved by adding a health protocol or pandemic fear questionnaire. This is to discover whether the anxiety experienced by expecting mothers is caused by things related to pregnancy or the pandemic. The authors can also guide the participants in filling out the questionnaire so that participants can ask questions.

Advice for expecting mothers is that they can find information about pregnancy on social media and consult online if you experience certain condition. For partners, when needed, they must pay attention and understand the condition of the mother, and keep a calm but alert attitude in dealing with the circumstances around them. For health facilities, they can adapt to technology to provide services in the form of information and facilities online to expecting mothers.

\section{REFERENCES}

[1] American Psychiatric Association. (2013). Diagnostic and statistical manual of mental disorders :
DSM-5 (5th ed.). American Psychiatric Association.

[2] Berk, L. E. (2012). Infants and children: Prenatal through middle childhood (7th ed.). Pearson.

[3] Bjelica, A., \& Nila, K.-S. (2004). Trudnoća kao psiholoski dogadaj [Pregnancy as a psychological event]. Medicinski Pregled, 57(3-4), 144-148. https:// doi.org/https://doi.org/10.2298/mpns0404144b

[4] Brunton, R. J., Dryer, R., Saliba, A., \& Kohlhoff, J. (2015). Pregnancy anxiety: A systematic review of current scales. Journal of Affective Disorders, 176, 24 34. https://doi.org/10.1016/j.jad.2015.01.039

[5] Brunton, R. J., Dryer, R., Saliba, A., \& Kohlhoff, J. (2019). The initial development of the Pregnancyrelated Anxiety Scale. Women and Birth, 32(1), e118e130. https://doi.org/10.1016/j.wombi.2018.05.004

[6] Cuncic, A. (2020). Generalized Anxiety Disorder During Pregnancy. Verywellmind. Generalized Anxiety Disorder During Pregnancy

[7] Dewi, F. K., Rini, S., \& Murniati. (2018). Pengetahuan Tentang Ibu Hamil Dalam Kesehatan Khususnya Anemia. Jurnal Kesehatan Al-Irsyad, XI(2), $45-51$.

[8] Diani, L. P. P., \& Susilawati, L. K. P. A. (2013) Pengaruh Dukungan Suami terhadap Istri yang Mengalami Kecemasan pada Kehamilan Trimester Ketiga di Kabupaten Gianyar. Jurnal Psikologi Udayana, 1(1), 1-11. https://doi.org/10.24843/jpu. 2013.v01.i01.p01

[9] Din, Z. U., Ambreen, S., Iqbal, Z., Iqbal, M., \& Ahmad, S. (2016). Determinants of antenatal psychological distress in Pakistani women. Noropsikiyatri Arsivi, 53(2), 152-157. https://doi.org/ 10.5152/npa.2015.10235

[10] Ding, X. X., Wu, Y. Le, Xu, S. J., Zhu, R. P., Jia, X. M., Zhang, S. F., Huang, K., Zhu, P., Hao, J. H., \& Tao, F. B. (2014). Maternal anxiety during pregnancy and adverse birth outcomes: A systematic review and meta-analysis of prospective cohort studies. Journal of Affective Disorders, 159(81), 103-110. https://doi.org/ 10.1016/j.jad.2014.02.027

[11] Field, T. (2017). Prenatal anxiety effects: A review. Infant Behavior and Development, 49(March), 120-128. https://doi.org/10.1016/j.infbeh.2017.08.008

[12] Healthwise. (2018). Emotional Changes During Pregnancy. Healthwise. https://www.healthlinkbc.ca/ health-topics/tn10071\#: :text=Happiness and anxiety 
about a,forgetful and disorganized than before.

[13] Hetherington, E., Doktorchik, C., Premji, S. S., McDonald, S. W., Tough, S. C., \& Sauve, R. S. (2015). Preterm Birth and Social Support during Pregnancy: A Systematic Review and Meta-Analysis. Paediatric and Perinatal Epidemiology, 29(6), 523-535. https://doi. org/10.1111/ppe.12225

[14] Hetherington, E., McDonald, S., Williamson, T., Patten, S. B., \& Tough, S. C. (2018). Social support and maternal mental health at 4 months and 1 year postpartum: Analysis from the All Our Families cohort. Journal of Epidemiology and Community Health, 72(10), 933-939. https://doi.org/10.1136/jech-2017210274

[15] Hopkins, J., Miller, J. L., Butler, K., Gibson, L., Hedrick, L., \& Boyle, D. A. (2018). The relation between social support, anxiety and distress symptoms and maternal fetal attachment. Journal of Reproductive and Infant Psychology, 36(4), 381-392. https://doi.org/ $10.1080 / 02646838.2018 .1466385$

[16] Hoyer, J., Wieder, G., Höfler, M., Krause, L., Wittchen, H. U., \& Martini, J. (2020). Do lifetime anxiety disorders (anxiety liability) and pregnancyrelated anxiety predict complications during pregnancy and delivery? Early Human Development, 144(September 2019), 105022. https://doi.org/10.1016/ j.earlhumdev.2020.105022

[17] Hu, T., Xiao, J., Peng, J., Kuang, X., \& He, B. (2018). Relationship between resilience, social support as well as anxiety/depression of lung cancer patients: A cross-sectional observation study. Journal of Cancer Research and Therapeutics, 14(7), 72-77. https://doi. org/10.4103/jcrt.JCRT_849_17

[18] Jalal, M., Dolatian, M., Mahmoodi, Z., \& Aliyari, R. (2017). The relationship between psychological factors and maternal social support to breastfeeding process. Electronic Physician, 9(1), 3561-3569. https:// doi.org/http://dx.doi.org/10.19082/3561

[19] Maharani, T., \& Fakhrurrozi, M. (2014). Hubungan Dukungan Sosial Dan Kecemasan Dalam Menghadapi Persalinan Pada Ibu Hamil Trimester Ketiga. Jurnal Ilmiah Psikologi Gunadarma, 7(2), 99481. https://doi.org/10.35760/psi

[20] Moyer, C. A., Compton, S. D., Kaselitz, E., \& Muzik, M. (2020). Pregnancy-related anxiety during COVID-19: a nationwide survey of 2740 expecting mothers. Archives of Women's Mental Health. https://doi.org/10.1007/s00737-020-01073-5
[21] Mustikawati, A. K., Harapan, A., \& Ponorogo, M. (2018). Keywords : Social Support, Anxiety, Expecting mothers. 9(8).

[22] Nath, A., Venkatesh, S., Balan, S., Metgud, C. S., Krishna, M., \& Murthy, G. V. S. (2019). <p >The prevalence and determinants of pregnancy-related anxiety amongst expecting mothers at less than 24 weeks of pregnancy in Bangalore, Southern India $</ p>$. International Journal of Women's Health, Volume 11, 241-248. https://doi.org/10.2147/ijwh.s193306

[23] Patimah, M., Husin, F., \& Effendi, J. S. (2019). Hubungan Dukungan Sosial dan Kecemasan Ibu Hamil Trimester I Primigravida di Kota Tasikmalaya. 12, 151-154.

[24] Pevzner, H. (2020). Your Pregnancy Week by Week. Verywellfamily. https://www.verywellfamily. com/pregnancy-your-week-by-week-guide-4159265

[25] Putri, G. S. (2020). Lebih dari 400.000 Kehamilan Baru Terjadi Selama Pandemi di Indonesia. Kompas.Com. https://www.kompas.com/sains/read/ 2020/05/20/110300923/lebih-dari-400.000-kehamilanbaru-terjadi-selama-pandemi-di-indonesia?page $=$ all

[26] Rinata, E., \& Andayani, G. A. (2018) Karakteristik ibu (usia, paritas, pendidikan) dan dukungan keluarga dengan kecemasan ibu hamil trimester III. Medisains, 16(1), 14. https://doi.org/10. 30595/medisains.v16i1.2063

[27] Shumaker, S. A., \& Brownell, A. (1984). Toward a Theory of Social Support: Closing Conceptual Gaps. Journal of Social Issues, 40(4), 11-36. https://doi.org/ 10.1111/j.1540-4560.1984.tb01105.x

[28] Silva, M. M. de J., Nogueira, D. A., Clapis, M. J., \& Leite, E. P. R. C. (2017). Anxiety in pregnancy: Prevalence and associated factors. Revista Da Escola de Enfermagem, 51, 1-8. https://doi.org/10.1590/S1980$220 \times 2016048003253$

[29] Tan, M. (2007). Social Support and Coping in Turkish Patients With Cancer. Cancer Nursing, 30(6), 498. http://search.proquest.com/docview/232025314? accountid=14477\% $5 \mathrm{Cnhttp}: / / \mathrm{xv} 2 \mathrm{~cd} 5 \mathrm{eg} 7 \mathrm{y}$. search.serials solutions.com/directLink?\&atitle=Social+Support+and +Coping+in+Turkish+Patients+With+Cancer\&author= Tan\%2C+Mehtap\%2C+PhD\&issn=0162220X\&title $=\mathrm{C}$ ancer+Nursing \&volum

[30] Tang, X., Lu, Z., Hu, D., \& Zhong, X. (2019). Influencing factors for prenatal Stress, anxiety and depression in early pregnancy among women in Chongqing, China. Journal of Affective Disorders, 
253(March), 292-302. https://doi.org/10.1016/j.jad. 2019.05.003

[31] Utomo, Y. D. C., \& Sudjiwanati, S. (2018). Pengaruh Dukungan Sosial Terhadap Tingkat Kecemasan Ibu Hamil Di Rumah Sakit Bersalin Pemerintah Kota Malang. Psikovidya, 22(2), 197-223. https://doi.org/10.37303/psikovidya.v22i2.117

[32] Van de Loo, K. F. E., Vlenterie, R., Nikkels, S. J., Merkus, P. J. F. M., Roukema, J., Verhaak, C. M., Roeleveld, N., \& van Gelder, M. M. H. J. (2018). Depression and anxiety during pregnancy: The influence of maternal characteristics. Birth, 45(4), 478489. https://doi.org/10.1111/birt.12343

[33] Yasin, Z., Sumarni, S., \& Mardiana, N. D. (2019). Hubungan Usia Ibu dan Usia Kehamilan dengan Kecemasan Ibu Hamil dalam Menghadapi Persalonan Di Polindes Masaran Kecamran Bluto. Prosiding 1st Seminar Nasional Dan Call for Paper, 162-168.

[34] Zimet, G. D. (1998). Evaluating Stress: A Book of Resources, Volume 2. In Evaluating Stress (pp. 185197). The Scarecrow Press, Inc.

[35] Zimet, G. D., Dahlem, N. W., Zimet, S. G., Gordon, K., \& Farley, G. K. (1988). The Multidimensional Scale of Perceived Social Support The Multidimensional Scale of Perceived Social Support. Journal of Personality Assessment, 52(1), 3041. https://doi.org/10.1207/s15327752jpa5201

[36] Bayrampour, H., Ali, E., McNeil, D. A., Benzies, K., MacQueen, G., \& Tough, S. (2016). Pregnancyrelated anxiety: A concept analysis. International Journal of Nursing Studies, 55, 115-130. https://doi. org/10.1016/j.ijnurstu.2015.10.023

[37] Kazdin, A. E. (2000). Encyclopedia of Psychology. American Psychiatric Association.

[38] Zincir, S. B. (2016). Generalized anxiety disorder. Psychiatric Disorders during the Postpartum Period in Light of Current Advances, 501(c), 83-90. https://doi. org/10.7326/0003-4819-159-11-201312030-01006

[39] Wall, V., Premji, S. S., Letourneau, N., McCaffrey, G., \& Nyanza, E. C. (2018). Factors associated with pregnancy-related anxiety in Tanzanian women: A cross sectional study. BMJ Open, 8(6), 1-8. https://doi. org/10.1136/bmjopen-2017-020056

[40] Agusdwitanti, H., Tambunan, S. M., \& Retnaningsih. (2015). KELEKATAN DAN INTIMASI PADA DEWASA AWAL. Jurnal Psikologi, 8(1), 1824.
[41] Sondakh, J. J., \& Yuliani, I. (2017). Kecemasan Antara Primigravida dan Multigravida dalam Menghadapi Proses Persalian. Jurnal Pendidikan Kesehatan, 6(1), 1. https://doi.org/10.31290/jpk.v(6)i(1) $\mathrm{y}(2017)$.page: $1-4$

[42] Kecemasan Ibu Hamil Meningkat Saat Pandemi Corona. (2020, April 24). VOA Indonesia. https:// www.voaindonesia.com/a/kecemasan-ibu-hamilmeningkat-saat-pandemi-corona/5390025.html

[43] Jiang, H., Jin, L., Qian, X., Xiong, X., La, X., Chen, W., \& Al, E. (2020). Evidence of accessing antenatal care information via social media platforms supports mental wellbeing in COVID-19 epidemic. [Submitted]. Bull World Health Organ. E-Pub:, March, $1-15$. 